\title{
AN ANALYSIS OF COMPENSATION COLLECTED FOR THE DEPLETION OF ANGOLA'S OIL RESOURCES
}

\author{
Pieter van der Zwan* \\ North West University \\ pieter.vanderzwan@nwu.ac.za
}

July 2011

\begin{abstract}
The African continent contributes approximately $12 \%$ of the world's oil production. Despite this wealth, many citizens of oil-rich African countries live in poverty, often because their governments do not collect sufficient compensation for the depletion of oil resources to fund national development or do not utilise compensation collected for the benefit of the people. In this article the extraction tax regime to collect compensation on Angola's oil resources is compared to the regimes in other oil-rich countries to identify aspects from which Angola can learn with regard to the compensation systems of those countries. It is concluded that Angola may be able to improve its extraction tax regime by learning from governance measures over natural resource funds in Norway and Canada, by implementing measures to increase its oil royalty income in times of economic prosperity and by defining deductible costs more specifically in its production-sharing agreements.
\end{abstract}

Keywords

Angolan oil resources, Angolan oil taxation, oil taxation, oil royalties, production-sharing agreements (PSA).

*Prof Pieter van der Zwan is an associate professor in the School for Accounting Sciences at North West University, Potchefstroom, South Africa. 


\section{INTRODUCTION}

"We are stripped bare by the curse of plenty." This statement, made by Winston Churchill in 1932, rings true for the economies of many resource-rich African countries today. The African continent produces approximately $12 \%$ of the world's oil (OPEC, 2010; CIA, 2009). The main contributors to this figure are Nigeria (2.62\%), Algeria (2.51\%), Angola (2.31\%) and Libya (2.12\%) (OPEC, 2010; CIA, 2009). Of the four main oil-producing countries in Africa, Angola's Human Development Index (HDI) ranking (143rd) is the second lowest after Nigeria, which is ranked 158th (UNDP, 2009). Angola has the lowest poverty ranking (HPI) $\left(114^{\text {th }}\right)$ of the four countries. Libya and Algeria are ranked significantly higher than Angola and Nigeria on both indicators. However, Nigeria has undertaken a process of comprehensively reforming its petroleum industry aimed at addressing this problem. Given its economic position despite the contribution to the continent's oil production, the focus of this article is on the Angolan petroleum industry.

The first oil exploration activities in Angola began in 1910, while commercial drilling commenced in 1956 (Rosenblum, 2011). The oil industry has grown to contribute more than $80 \%$ to Angola's $\operatorname{GDP}(C|A, 2011 ; \varepsilon| A, 2010)$ and approximately $90 \%$ to the country's total exports ( $(I A, 2010)$. As a result of the Angolan economy's high dependence on the oil industry, the economy is exposed to volatility in oil prices, as was illustrated by its economic growth of merely $2.4 \%$ in 2009 when oil prices fell sharply $(\mathrm{CIA}, 2011)$ in comparison to its double-digit growth between 2003 and 2008 (CIA, 2011). Despite its oil wealth, it is estimated that between $40 \%$ and $50 \%$ of the Angolan population live below the poverty line and do not share in the benefits of the country's oil resources (CIA, 2011).

The paradoxical phenomenon where countries with substantial natural resource wealth, such as Angola, experience economic and political problems is referred to in the literature as the resource curse (Bastida, Wälde \& Warden-Fernández, 2005). Countries that suffer from the resource curse experience slower economic growth than countries without these mineral resources (Mehlum, Moene \& Torvik, 2006) or stagnate economically (Sachs \& Warner, 2001), have poor standards of living as a result of general economic underperformance (Auty \& Mikesell, 1998; Sarraf \& Jiwanji, 2001) and often experience civil conflict that stems from the resource wealth (Mikesell, 1997). The resource curse has in particular been prevalent in countries with hydrocarbon wealth, such as natural gas and petroleum (Ernst, 2007, Sala-iMartin \& Subramanian, 2003).

However, the resource curse is not necessarily the fate of all resource-rich countries (Sarraf \& Jiwanji, 2001). This curse can be broken by implementing sound fiscal and monetary policies as well as by good management of windfall profits (Larsen, 2003; Bastida et al., 2005). One component of the fiscal policies to manage a country's mining activities is a transparent and balanced mining tax regime (Lambrechts, Darinami, Kabemba \& Olaleye, 2009). The African Union has recognised that mining activities, if well managed, can contribute to the transformation of the continent's economies (Lambrechts et al., 2009). Mining activities in Africa are often conducted by foreign mining companies that import equipment and expertise. In view of the fact that the mining industry is capital-intensive and creates relatively few job opportunities compared to other industries, UNCTAD (2007) is of the opinion that one of the most important developmental benefits of mining in Africa is the potential to generate public revenue through an effective and transparent tax system.

Governments use a variety of instruments to collect a share of the nation's resource wealth 
(Otto, Andrews, Cawood, Doggert, Guj, Stermole, Stermole \& Tilton, 2006), including income taxes, royalties and production-sharing agreements (Alberta Energy, 2009). An ideal fiscal system may consist of a mix of these instruments (Lund, 2009; 0tto et al., 2006). Royalties and the state's share from production-sharing agreements are collected from extractors to compensate the owner (in most instances the state) for the depletion of non-renewable resources (0tto et al., 2006; Lund, 2009). The government's take from these instruments is strictly speaking not classified as taxes, as they are often not based on profitability. These payments collected to compensate the state for the depletion of non-renewable resources are collectively referred to as extraction taxes in this article.

Resource export-dependent countries often rely heavily on extraction taxes that do not take into account the profitability of the extractor (0tto et al., 2006). This is evidenced by the fact that most of the tax collected by African governments stems from royalties (Lambrechts et al., 2009). Furthermore, extraction taxes provide the government with revenue as soon as the country's resources are depleted, whereas traditional taxes determined with reference to profits often result in a deferral of revenue payments to the government as a result of deductions for initial capital expenditure, which can be offset against subsequent income (UNCTAD, 2005). It has been observed that countries often receive negligible revenue from income tax in the petroleum industry because of deductions and allowances available (0chieze, 2007; 0tto, 2001). Extraction taxes are easy to administer and difficult to avoid due to their simple calculation (for example, revenue multiplied by a rate), providing a government with a less sophisticated tax-collection system with an ideal way of collecting revenue (0tto et al., 2006). Erikson (2006) noted that the system of royalties, which is an extraction tax, was one of the most important instruments in the early life of the successful Norwegian oil tax system, as it contributed to the establishment of an effective tax system by providing an early income to the state.

\section{RESEARCH PROBLEM}

The purpose of the research that this article reports on is to evaluate the design of Angola's petroleum tax regime in order to identify aspects that can be improved on in order to address the country's economic conditions. Angola is a net petroleum exporter ( $E I A, 2010)$, does not have a sophisticated tax collection system and is still in the process of establishing an effective petroleum tax regime. Given the importance of extraction taxes as discussed above, the research evaluated the design of extraction taxes collected in Angola as compensation for the depletion of the country's petroleum resources. The research question considered was whether there were any aspects of the extraction taxes imposed by Angola that could be improved to address the country's poverty and economic conditions. This research question was answered by comparing the petroleum extraction tax regime in Angola to that of a selection of other petroleum-producing countries to identify aspects where Angola can improve on its regime by learning from those countries. The evaluation of Angola's income tax system was not within the scope of the research; therefore it will not be addressed in this article. In addition, the level of compensation collected was not evaluated. The optimal level of mining tax in a country depends on numerous factors such as the costs of extracting the oil resources, geological factors, and political, regulatory and environmental risks and objectives (Alberta Energy, 2009; 0tto et al., 2006) and is therefore not necessarily comparable between Angola and other countries.

The remainder of this article provides a discussion of the research design (section 3), a brief 
overview of the results of the comparison between the Angolan extraction tax system and that of a selection of oil-producing countries (section 4) and a discussion of the application of the aspects identified in section 4 in the Angolan context (section 5). The article concludes with recommendations in section 6 .

\section{RESEARCH DESIGN}

The study was conducted by reviewing the literature available on legislation that imposes royalties in Angola as well as the other petroleum-producing countries selected. The method described in this section was used to select the countries to include in the comparison. A comparison was done between key aspects of the legislation imposing extraction taxes in Angola and the other countries selected to identify aspects of these regimes from which Angola can learn. The application of each of the aspects identified in the Angolan context was explored by surveying the literature available.

For the study to achieve its purpose, the countries with which the Angolan extraction tax regime were compared had to be significant contributors to the world petroleum production and had to be economically successful. The first selection criterion was to identify countries based on their contribution to the world's total petroleum production. All countries that contribute $1 \%$ or more to the world's oil annual oil production according to the CIA World Factbook were considered. The 23 countries indicated in TABLE 1 exceeded this threshold. These countries contain approximately $96 \%$ of the world's proven oil reserves and produce $87.27 \%$ of the world's annual oil production (CIA, 2009; CIA, 2010). To select countries that have achieved economic success from this list, indicators that incorporate income performance such as the Gross Domestic Product (Van den Bergh, 2009) as well as non-income indicators such as poverty, health and education (Bourguignon \& Charkravarty, 2003) were considered. The Human Development index (HDI), a composite index published by the UNDP, reflects income and non-income measures that indicate a country's achievements in three basic aspects of human development, namely health, knowledge, and a decent standard of living (UNDP, 2009). As the study focused on Angola because of the poverty of its people, the Human Poverty Index (HPI), which measures the most basic dimensions of deprivation in terms of deprivation of knowledge, a basic decent living standard as well as longevity (UNDP, 2009), was considered. Lastly, a lack of transparency and dysfunctional behaviour, specifically corruption, has been identified as one of the main causes of the poverty in Angola (Kolstad \& Søreide, 2009). Therefore the 2009 Corruption Perception Index (CPI) as published by Transparency International was used to select the countries that have been successful in addressing corruption.

The 23 countries were ranked relative to each other on the three indices mentioned above. An overall ranking was calculated as the weighted average of the three relative rankings. The topranked country (based on the weighted average rankings) from each continent was selected in order to include a variety of views, policies and designs used in different regions of the world in the study.

TABLE 1 summarises the relative rankings for each of the 23 countries for each of the indicators discussed above. In all instances, a low ranking indicates a favourable indicator. 
Van der Zwan

TABLE 1: Ranking of the selected oil-producing countries relative to each other based on the HDI, HPI and CPI

\begin{tabular}{|c|c|c|c|c|c|c|}
\hline Country & $\begin{array}{l}\% \text { of } \\
\text { reserves } \\
(C I A, 2010\end{array}$ & $\begin{array}{l}\% \text { of world } \\
\text { production } \\
(C I A, 2009)\end{array}$ & $\begin{array}{c}C P I \\
\text { ranking }\end{array}$ & $\begin{array}{c}H D I \\
\text { ranking }\end{array}$ & $\begin{array}{c}\text { HPI } \\
\text { ranking }\end{array}$ & $\begin{array}{l}\text { Overall } \\
\text { ranking }\end{array}$ \\
\hline Norway & $0.48 \%$ & $2.79 \%$ & 2 & 1 & 1 & 1 \\
\hline Canada & $12.87 \%$ & $3.90 \%$ & 1 & 2 & 2 & 2 \\
\hline United Kingdom & $0.25 \%$ & $1.78 \%$ & 3 & 4 & 4 & 3 \\
\hline United States of America & $1.54 \%$ & $10.75 \%$ & 4 & 3 & 5 & 4 \\
\hline Qatar & $1.96 \%$ & $1.44 \%$ & 5 & 6 & 3 & 5 \\
\hline United Arab Emirates & $7.07 \%$ & $3.32 \%$ & 6 & 7 & 9 & 6 \\
\hline Mexico & $0.96 \%$ & $3.56 \%$ & 12 & 8 & 6 & 7 \\
\hline Saudi Arabia & $19.08 \%$ & $11.59 \%$ & 7 & 11 & 14 & 8 \\
\hline Brazil & $0.91 \%$ & $3.05 \%$ & 9 & 13 & 12 & 9 \\
\hline China & $1.13 \%$ & $4.74 \%$ & 10 & 17 & 10 & 10 \\
\hline Venezuela & $7.12 \%$ & $2.93 \%$ & 20 & 10 & 7 & 10 \\
\hline Russia & $5.71 \%$ & $11.79 \%$ & 19 & 12 & 8 & 12 \\
\hline Kazakhstan & $2.17 \%$ & $1.83 \%$ & 15 & 14 & 11 & 13 \\
\hline Libya & $3.32 \%$ & $2.12 \%$ & 16 & 9 & 16 & 14 \\
\hline Azerbaijan & $0.51 \%$ & $1.20 \%$ & 18 & 15 & 13 & 15 \\
\hline Algeria & $1.09 \%$ & $2.52 \%$ & 13 & 18 & 18 & 16 \\
\hline Indonesia & $0.28 \%$ & $1.21 \%$ & 13 & 19 & 17 & 16 \\
\hline India & $0.41 \%$ & $1.04 \%$ & 11 & 20 & 20 & 18 \\
\hline Iran & $9.94 \%$ & $4.95 \%$ & 22 & 16 & 15 & 19 \\
\hline Nigeria & $2.62 \%$ & $2.62 \%$ & 16 & 22 & 21 & 20 \\
\hline Angola & $0.98 \%$ & $2.31 \%$ & 20 & 21 & 22 & 21 \\
\hline Kuwait & $7.33 \%$ & $2.96 \%$ & 8 & 5 & $\mathrm{~N} / \mathrm{A}$ & $\mathrm{N} / \mathrm{A}$ \\
\hline Iraq & $8.20 \%$ & $2.85 \%$ & 23 & $\mathrm{~N} / \mathrm{A}$ & 19 & $\mathrm{~N} / \mathrm{A}$ \\
\hline
\end{tabular}

Source: Author's deduction (sources at each column in column heading)

N/A = No ranking could be calculated as the indicators were not available for these countries.

Based on the selection process described, Norway (Europe), Canada (North America), Brazil (South America) and (latar (Asia) were included in the study. Qatar was substituted with the United Arab Emirates, the second-ranked Asian country, due to a lack of information on Qatar's extraction tax regime. Secondary information was available on the oil concession agreements of Abu Dhabi (United Arab Emirates).

\section{RESULTS OF THE COMPARISON OF EXTRACTION TAX REGIMES}

This section provides an overview of the comparison between the extraction tax legislation in Angola and the countries selected in section 3 in TABLE 2. It concludes by identifying aspects 
that Angola may be able to learn from each of the other countries.

\subsection{Comparison between relevant legislation}

TABLE 2 provides a high-level comparative overview of the aspects of the extraction tax regimes of the countries included in the study. The extraction tax regime of Alberta was included in the study as the bulk of Canada's oil reserves are found in Alberta ( $(I A, 2009 a)$. The United Arab Emirates does not have a federal oil policy or federal petroleum legislation. As oil policy is left to the jurisdiction of each member emirate, the emirate of Abu Dhabi, which contains the majority (approximately 94\%) of the United Arab Emirates' oil reserves (Suleiman, s.a.; $\varepsilon \mid A, 2009 b)$, was used in the comparison.

\subsection{Areas identified for further consideration}

The comparison in 4.1 provides evidence of a number of differences between the legislation to collect compensation for the depletion of petroleum resources in Angola and each of the other countries. The main areas identified from this comparison for further consideration in the Angolan context are the following:

- Angola implemented royalties in certain regions and production-sharing agreements in others. Alberta and Brazil only make use of royalties to collect compensation for the depletion of their oil resources. The effectiveness of production-sharing agreements as instruments to collect compensation in Angola is considered in section 5.1.

- The extraction tax regimes in Alberta, Brazil and Abu Dhabi provide for an increase in government take when oil prices and/or production levels increase. Angola's take from its royalty regime does not increase in times of economic prosperity. Measures to enable the Angolan government to share in wealth during times of economic prosperity are considered in section 5.2 .

- Alberta and Norway established funds to account for and manage oil revenues. The use of such a fund in Angola is discussed in section 5.3.1. In Brazil oil revenues are distributed directly to beneficiaries to ensure appropriate use and accountability. This measure, as an alternative to establishing a fund, is considered in section 5.3.2.

- The Norwegian state shares in the country's oil wealth through resource rent taxes. In both Norway and Abu Dhabi the state makes direct investments in oil projects. The use of a resources rent tax system and direct investment in petroleum projects in Angola are discussed in section 5.4 .

- Lastly, it has been identified that the instances where relief is available in terms of Alberta's extraction tax regime are defined more clearly than those in the Angolan royalty regime. As vague relief provisions may result in misuse or abuse of these provisions, it is recommended that the Angolan regime can be improved by clearly defining instances in which relief would be available.

The appropriateness of each of these areas in the Angolan context is considered in section 5 . 


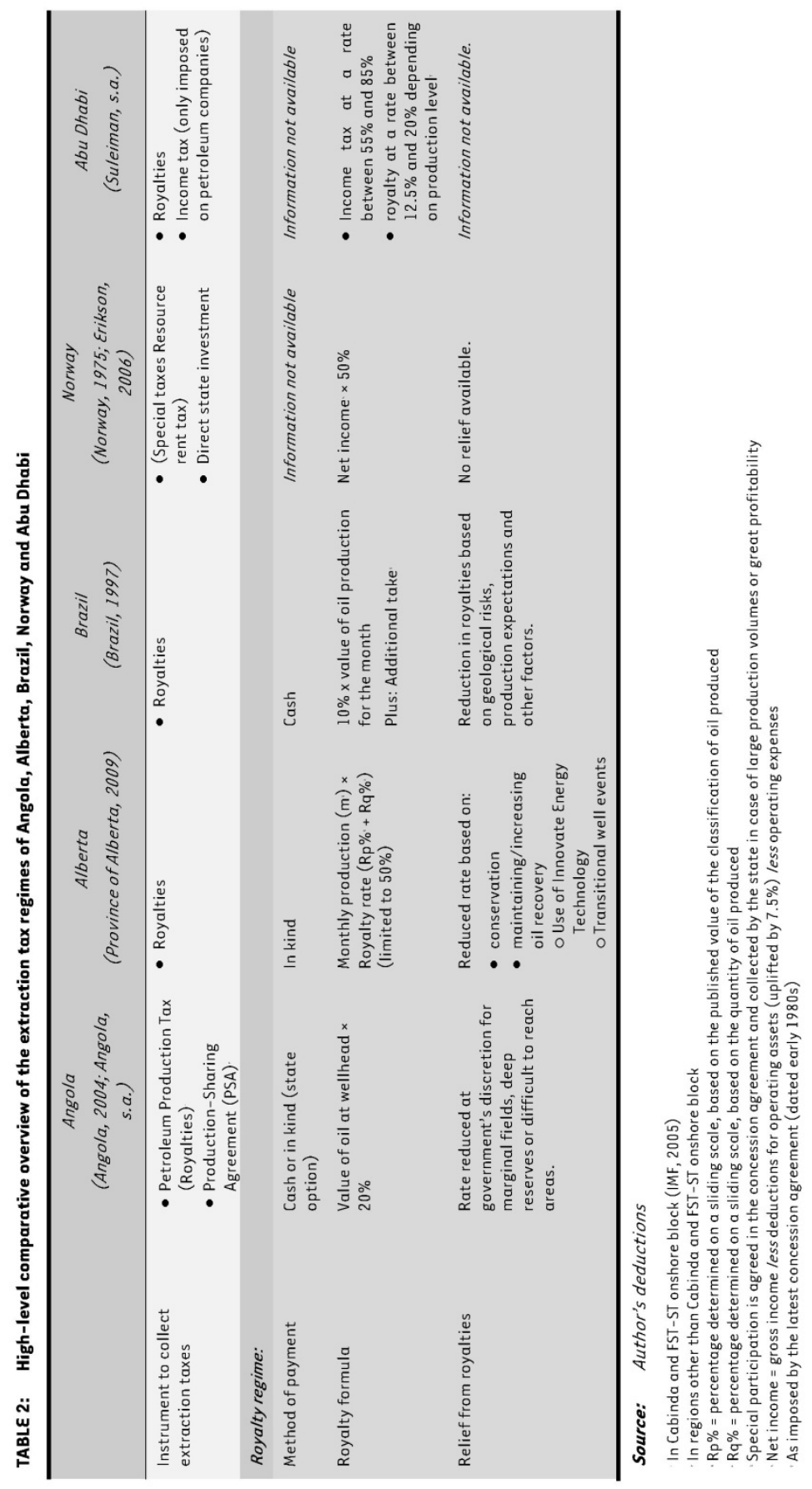




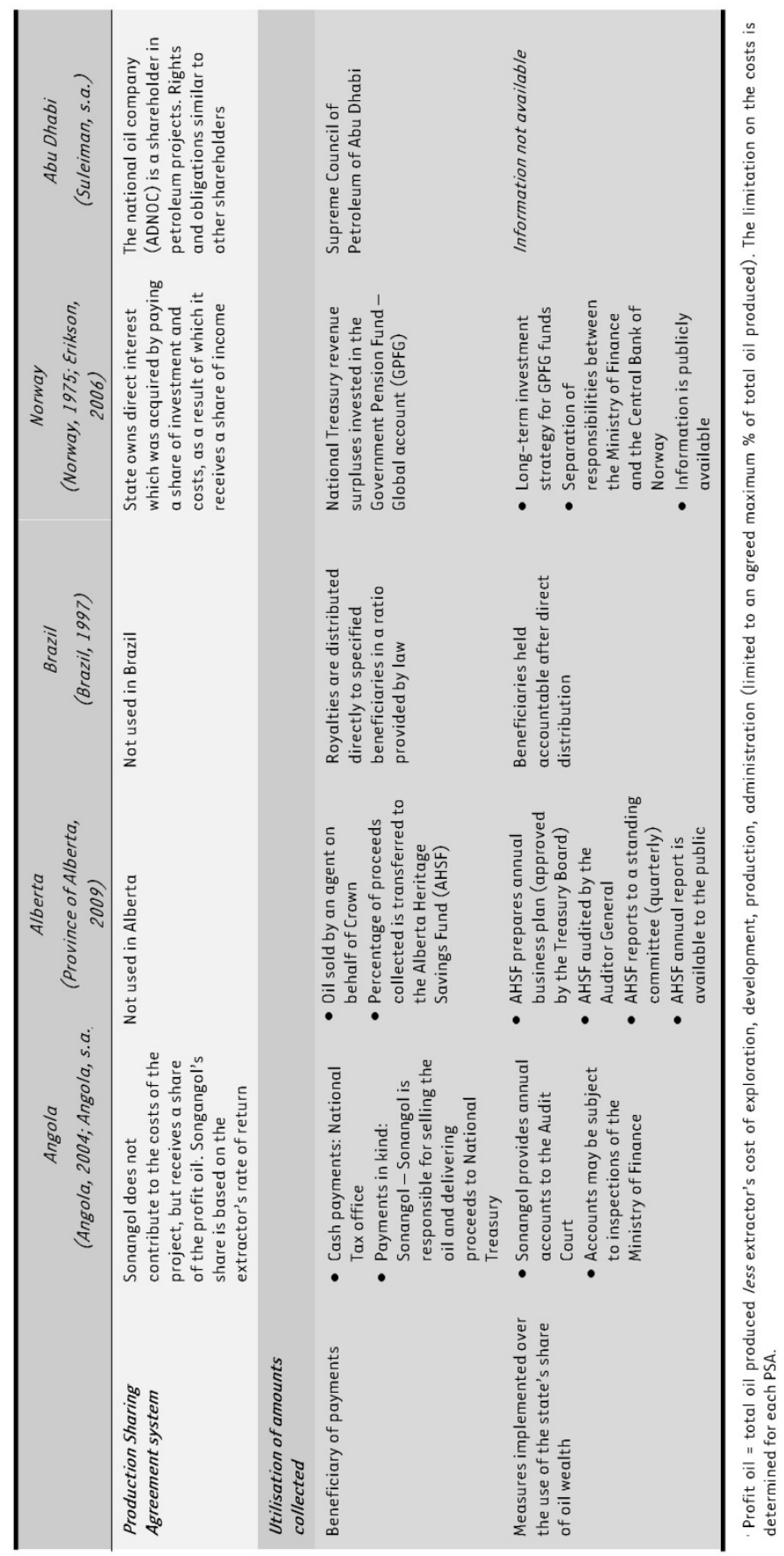




\section{DISCUSSION OF ASPECTS THAT ANGOLA CAN LEARN FROM}

The aspects of the extraction tax regimes of Alberta, Brazil, Norway and Abu Dhabi that were identified in section 4.2 are discussed in this section to determine whether Angola can learn from these aspects to improve its extraction tax regime.

\subsection{Effectiveness of production-sharing agreements to collect compensation on petroleum resources}

In section 4 it was observed that Angola is the only country in the comparison that makes use of production-sharing agreements (PSA). Canada, Brazil and Abu Dhabi use royalties, while Norway imposes a resource rent tax (special tax) and makes direct investments in petroleum projects. This poses the question whether the use of production-sharing agreements is a suitable instrument to collect compensation on Angola's petroleum resources.

Farhan (2008) argues that from a functional and financial point of view a PSA system is not different from a concessionary (royalty) system. The differences between the two systems lie in the management and control of the operations of international oil companies that explore a country's petroleum resources. The benefit of a PSA system for the government (or national oil companies) is that it shares in the revenue and has an influence in the exploration and development operations, while it does not bear any of the exploration risks involved with the petroleum project (Bindemann, 1999). In essence, the government controls the petroleum activities and petroleum output and pays a share of the output to the operator as a reward for the services provided and the risks accepted (Bindemann, 1999). In the case of concession agreements, the government does not control the operations or own the output. In comparison with a PSA system, the use of direct financial interests exposes the state to more risks, as it bears exploration risk by contributing to the operating and exploration costs.

Despite the benefit of being involved in the operations of a petroleum exploration and development project as described above, there are a number of reasons why a PSA system is not favoured by all petroleum-producing countries. Wälde (1995) contends that restrictions in the agreements often limit the influence of the government severely. Consequently, governments merely create the perception of control over the petroleum activities while at the same time a PSA system may expose them to other disadvantages (discussed below). This problem regarding the use of a PSA system can however be overcome by drafting and negotiating agreements to provide the government with sufficient influence in petroleum activities.

Moreover, a PSA system often binds the government for long periods of time, making this system less flexible when the economic or political climate changes (Muttitt, 2005). However, such a long-term agreement provides fiscal stability to foreign oil companies investing in high-risk projects in a country (Rutledge, 2004). This would be particularly relevant when the exploration risk is high if the oil fields have not yet been discovered, which is the case in the Angolan offshore fields where the PSA system is used (IMF, 2005). This characteristic of PSAs would therefore encourage foreign investment in Angola's petroleum industry.

Another characteristic of the PSA system that could be less favourable than a royalty system is that the government will share in profit oil, which is determined as the oil produced less costs (Bindemann, 1999). This implies that the government's share of the oil is determined on the basis of the profitability of the project. Petroleum resources can therefore be depleted at little 
or no compensation when profits are low as a result of high operating costs. Bindemann (1999) notes that royalties can be collected as part of the PSA to ensure that the state receives a minimum level of compensation irrespective of the profitability of the extractor. If the costs that can be deducted to determine profit oil are capped at a certain level, this serves the same purpose as a royalty (IMF, 2005; Rutledge, 2004). In the case of Angola's production-sharing agreements, the standard PSA template makes provision for a cap. Muttitt (2005) notes that profit taxes, such as the state's share of profit oil, are more complicated to determine and can be avoided by accounting techniques. It is therefore of critical importance that the PSA clearly defines the inputs into the profit calculation, especially the deductible costs, to avoid this. In the standard Angolan PSA template (Angola, s.a.), the costs to be deducted when calculating profit oil are stated widely as "all Exploration, Development, Production and Administration and Services Expenditures incurred under this Agreement". This wide definition of deductible costs may leave room for manipulation and is an area of the standard PSA template that could be improved. The ability to administrate this aspect of the PSA system may impact on the effectiveness of PSAs as an extraction tax instrument in Angola (Muttitt, 2005).

From the above discussion it is evident that a production-sharing agreement system may provide certain benefits to Angola, as it provides the state with a certain extent of control over the country's petroleum activities while encouraging foreign investment at the same time. This foreign investment is accompanied by knowledge and technology that may not be available in Angola. Even though this extraction tax instrument may have some disadvantages, they can be reduced or eliminated by the terms of the PSA. The fact that Angola uses production-sharing agreements in some regions is therefore not an area that requires improvement, although the other countries mentioned in the study do not make use of this system.

Two areas for further research that may improve Angola's PSA system have been identified in the discussion above. Research in these areas can ensure that the Angolan PSAs address the weaknesses of the PSA system, as identified above, sufficiently. Firstly, research can be performed to evaluate whether the Angolan PSAs have been drafted in such a way that the government has sufficient involvement in petroleum activities to justify using this form of extraction tax. This issue has proved to be problematic elsewhere in the world. Secondly, the sufficiency of the level of royalties (or the cap on costs to be deducted when determining profit oil) can be evaluated.

\subsection{Measures to share in the wealth in times of economic prosperity}

In the comparisons with Alberta, Brazil and Abu Dhabi it was observed that these countries have measures included in their extraction tax regimes to ensure that the state's share of petroleum revenues increases in times of economic prosperity. Angola has no similar measure in its royalty regime where the royalties are levied at a rate of $20 \%$ in all circumstances (unless it has been reduced to provide relief). The standard PSA template makes provision for an increase in the state's share of profit oil when the rate of return generated by the operator increases. This mechanism would capture additional compensation when the oil price rises or when operators reap the benefits of large production volumes.

Lambrechts et al. (2009) identified this concern when they commented that African governments have neither been able to optimise mining tax revenue during the 2003-2008 boom nor capture any price windfalls during this period. The observation is further supported by the fact that there has been a decline in Angola's share of oil revenue in a time when production increased from 2000 to 2003 (IMF, 2005). 
It is recommended that Angola consider including measures in its royalty regime to increase its share of the oil revenue wealth when oil prices increase or when production levels increase. The following suggested measures are based on the comparisons in section 4:

- An additional special take can merely be collected in specified circumstances where petroleum prices are high or production levels great, as is done in Brazil.

- A sliding royalty rate, which is based on either production level (as is the case in Abu Dhabi) or both the production level and the oil price (as is the case in Alberta), can be used to increase the state's compensation in times of economic prosperity. This is the most common method used to create a flexible tax regime (Ochieze, 2007).

\subsection{Management of petroleum revenue collected}

The comparisons in section 4 highlight the fact that the other countries implement stricter measures for managing and using the revenue collected from their petroleum resources than Angola. The appropriateness of these measures in the Angolan context is discussed in this section.

\subsubsection{The use of a sovereign wealth fund as a measure to improve management and use of petroleum revenue in Angola}

The first tool for managing petroleum revenue that was identified in the comparison with Canada and Norway is the use of a sovereign wealth fund. Natural resource revenue funds are created to serve as a mechanism to stabilise fiscal policy but also to save a portion of this revenue. Stabilisation funds are used to smooth expenditure funded from volatile natural resource revenue by channelling excess revenue into the fund in order to finance expenditure when natural resource revenue is low (Tsalik, 2004; Koptis, 2004; Davis, Ossowski, Daniel \& Barnett, 2001). The purpose of an investment fund, on the other hand, is to gather wealth from current natural resource activities to be used by future generations (Tsalik, 2004; Erikson, 2006). In addition, these funds can be used to prevent weakening of local currency if the revenues from exports are invested abroad. Lastly, the funds serve a transparency and accountability purpose (Tsalik, 2004; Koptis, 2004).

It has been reported on a number of occasions that the Angolan government is considering implementing a sovereign wealth fund to manage its expected income from increased oil production in future (SWFI, 2009; Almeida, 2008). Although these funds serve their purpose extremely well in countries such as Norway and Canada (Tsalik, 2004), there are mixed views on the use of funds as a solution to petroleum revenue management, as this approach has not always been effective in all countries that have implemented it (Gallagher \& Rozner, 2007).

Davis et al. (2001) state that stabilisation funds smooth expenditure by imposing limits on the liquidity available. They are of the opinion that these constraints on expenditure should be imposed by making a fiscal policy decision regarding expenditure. The creation of a fund is a tool that can be used in this process, but it will not automatically resolve the problem if no fiscal policies are implemented with regard to government spending. This means that the issue can be addressed equally well with or without the use of a natural resource fund. In addition, Davis et al. (2001) argue that natural resource funds may be difficult to integrate with the national budget, causing problems when coordinating government expenditure. 
Similarly, Davis et al. (2001) argue that a fund will not automatically lead to increased government savings when budget shortfalls created by saving revenues in a fund would have to be financed by government debt. Effective saving of government revenue would require a fiscal policy decision to be successful rather than being effected merely via the introduction of a fund. In Angola, a country where the masses live in poverty after a 27 -year civil war, immediate social expenditure may be perceived as being more important than saving wealth for future generations (Lundberg, Karan \& Ernst, 2007). This could result in no money being saved in the fund. This concern is illustrated by the Venezuelan situation, where the introduction of a natural resource fund has not been as successful as the Norwegian one even though the two were based on the same model. The socioeconomic conditions in Venezuela at the time when the fund was created required immediate government spending in areas such as health care, education, social programmes and infrastructure rather than saving of revenues for future generations (Koptis, 2004; Tsalik, 2004). The present conditions in Angola may create expenditure pressures on the government, similar to those in Venezuela, to address the socioeconomic conditions first before accumulating wealth. This would reduce the effectiveness of the creation of a fund significantly.

It is therefore submitted that the lesson to be learnt by Angola from the countries in the comparison is not that a fund should be created to manage its oil revenues collected. The view exists that the real value added by a natural resource revenue fund lies in the fact that it forces governments to plan revenue management and be transparent about it (Tsalik, 2004). It is therefore recommended that Angola learn from the governance measures implemented by the other countries with regard to their natural resource funds. The Norwegian and Canadian measures identified in the comparison in section 4, and from which Angola can learn, are the following:

- Firstly, the legislation in respect of the Alberta Heritage Savings Fund (Province of Alberta, 2000) requires the fund owners to prepare a business plan in relation to the use of funds. This business plan becomes part of a report that is made publicly available to enhance transparency and accountability regarding the use of oil revenue. Similarly, the Ministry of Finance in Norway is required to define a long-term investment strategy for amounts in the State Pension Fund - Global. Davis et al. (2001) suggest that fiscal budgeting can be performed without the use of a fund. This can be achieved by implementing mechanisms to guide short-, medium- and longterm expenditure to be funded from oil revenue based on the country's needs (Lundberg et al., 2007).

According to the Human Rights Watch (2010) the Angolan government had to approach the International Monetary Fund for funding in 2009 when the oil price declined. This indicates that government expenditure follows the economic cycles of the oil price and that sufficient provision is not made for periods when the oil price decreases. As indicated at the start of the article, Angola is ranked only $143^{\text {rd }}$ out of 182 countries on the Human Development Index (UNDP, 2009), indicating that expenditure does not necessarily benefit the people of Angola. It is therefore recommended that a mechanism be designed and implemented in Angola to force the government to plan expenditure in the short, medium and long term in such a way that the needs of the Angolan people are addressed. This planning mechanism should take into account and counteract future fluctuations in the oil price.

- Secondly, in both Alberta and Norway information on the oil revenue received, investment thereof as well as the expenditure funded from it is made public. In 
addition, the business plan referred to earlier is included in a document that is made available publicly. Both countries require the funds to be audited and the audit results are made public. This transparency creates a sense of public ownership over the oil funds and increases the state's accountability towards the business plan (or similar measure to manage use of the oil revenue) as well as actual expenditure funded from it (Tsalik, 2004). According to Tsalik (2004), this transparency has been a key factor in the success of countries like Norway and Alaska, while a lack of transparency contributed to the abuse of both Venezuela's and Oman's oil funds.

In Angola revenue information is publicly available on the Ministry of Finance website, but expenditure information is not. Expenditure information is critical if an oil fund is to benefit the people of Angola (Human Rights Watch, 2010; World Bank, 2006). Sonangol, the Angola's state petroleum company, is audited, but the audit report is not made available publicly (Human Rights Watch, 2010).

It is therefore recommended that the mechanism for planning expenditure, as discussed above, the actual information on expenditure, as well as the audit report on this expenditure be made available publicly in Angola to increase accountability in respect of the use of oil revenue.

- Lastly, the Alberta Heritage Fund Act involves the Treasury Board, Ministers of Finance and Revenue as well as a standing committee in the management of the province's oil revenue. The duties of managing the Government Pension Fund - Global are divided between the Ministry of Finance and the Central Bank of Norway. According to Tsalik (2004) an effective oversight system in managing oil revenue is vital to the success of the system. It is therefore recommended that the powers and authority for implementing and monitoring the recommendations above be divided between a number of independent entities in Angola.

\subsubsection{Other measures to improve management and use of petroleum revenue in Angola}

The comparison between Angola and Brazil identified the direct distribution of oil revenue to beneficiaries in Brazil as an aspect from which Angola can learn. Various commentators have noted that the direct distribution system did not improve economic performance and economic indicators significantly (Postali, 2009). It is submitted that this direct distribution mechanism could be a method to facilitate the implementation of the recommendations in section 5.3.1., but that this mechanism by itself will not contribute to the improvement of socio-economic conditions in Angola.

\subsection{Resource rent taxes and direct investment}

The last observation from the comparisons in section 4 is the principle of collecting compensation based on a profit basis in Norway as opposed to a sales value basis, which ignores the producer's profitability. In 1975 Garnaut and Clunnies-Ross (1975) argued that tax levied on the extraction of mineral resources should be neutral in order not to distort investors' decisions. They suggested a resource rent tax which is based on profit rather than gross sales. The profitbased compensation collected in Norway is an example of this type of tax. Compensation that is based on profitability exposes the state to greater risk than an ad valorem compensation that does not take the producer's profitability into account (0tto et al., 2006). A resource rent tax can result in low or no compensation if the profitability of the producer is low. Because it takes 
costs into account, these taxes are also more difficult to administer and easier to evade than ad valorem royalties (0tto et al., 2006). Direct investments in petroleum projects that are made in Norway and Abu Dhabi expose governments to similar risk. The main argument for using this system is that it will not distort investment decisions, and this should encourage investment.

Lambrechts et al. (2009) are of the opinion that the favourable tax regimes designed to encourage foreign investment that were introduced in Africa in the 1990s contributed to the fact that African countries did not collect their fair share of oil wealth. Angola is attracting foreign investment with its current regime, and this country is considered to be a petroleum investment hotspot (Frynas \& Paulo, 2006). It is therefore concluded that a profit-based compensation may become appropriate at a later stage in Angola's development when its oil fields start to mature and it becomes more difficult to attract foreign investment. For the same reason, direct investment by the state in Angolan petroleum projects is not advisable at this point in time.

\section{CONCLUSION AND RECOMMENDATIONS}

In section 4, the extraction tax regime in Angola was compared to those in Canada, Brazil, Norway and the United Arab Emirates in order to identify aspects of the design of the regimes in these countries that Angola can learn from to improve its extraction tax regime. The aspects identified in the comparison were considered in the context of Angola in section 5. In conclusion, recommendations are made for the improvement of various aspects of the design of Angola's extraction tax regime:

- The use of production-sharing agreements does not impact on the effectiveness of Angola's extraction tax regime. The production-sharing agreements can however be improved by clearly defining the allowable costs that can be deducted in determining profit oil.

- Relief measures in Angola's royalty legislation could be defined more clearly to prevent misuse and subjective relief being provided.

- Angola could introduce a measure into its royalty regime to ensure that the country shares in increased wealth in times of economic prosperity. This can be achieved by introducing a progressive royalty rate that depends on the oil price and level of production (similar to Alberta and Abu Dhabi) or by introducing an additional take if production levels or the oil price exceeds certain levels (similar to Brazil).

- Mechanisms could be introduced to improve planning as well as accountability over expenditure funded from oil revenue. This would not necessarily entail the use of a sovereign wealth fund, even though such a fund can facilitate the implementation and execution of these mechanisms. Based on the comparison, it is recommended that a formal expenditure planning or budget process be introduced to ensure that oil funds are used in areas where they benefit the people of Angola. Information on this plan or budget, actual expenditure and the audit report on expenditure should be made available publicly to improve the state's accountability. Authority and responsibility for this process should be divided between a number of independent entities to ensure effective oversight over and functioning of the mechanisms.

The discussion in section 5.1 identified two aims for further research that may improve the effectiveness of Angola's PSA system. These are, firstly, to evaluate whether Angola's current 
PSAs provide the state with sufficient involvement in petroleum activities, and, secondly, to determine whether the cost caps that have been set in the PSAs provide Angola with a sufficient level of royalties from these agreements.

Angola is a country that is already realising its potential as a major player in the world petroleum industry. This article has contributed to the existing literature by identifying aspects of legislation imposed in other petroleum-producing countries that Angola can use to turn its substantial oil reserves into a blessing for all rather than a curse for the masses.

\section{LIST OF REFERENCES}

Alberta Energy. (2009). Alberta's Royalty Framework-Jurisdictional Comparison. [Online] Available: http://www.energy.alberta.ca/org/pdfs/royalty_jurisdiction.pdf. (Accessed 28 August 2010).

Almeida, H. (2008). Angola says to launch sovereign wealth fund. Reuters. [On-line] Available: http://www.reuters.com/article/idUSB5865920081120. (Accessed 10 November 2010)

Angola. (2004). Law of Taxation of Petroleum Activities (Law 13/04) (Translation). [0n-line] Available:

http://www.ogel.org/search/get_page.asp?v2=legal\&vl=angola\%5Fpetroleum\%5Factivities\%5Flaw $\% 5 F 2004 \% 2 \varepsilon p d f$. (Accessed 28 August 2010)

Angola. (s.a.) Standard PSA template (Translation). [0n-line] Available:

http://www.ogel.org/search/get_page.asp?v2=legal\&vl=model\%5Fpsc\%5Fof\%5Fangola\%2Epdf. (Accessed 28 August 2010)

Auty, R.M. \& Mikesell, R.F. (1998) Sustainable development in mineral economies. 0xford: 0xford University Press.

Bastida, દ., Wälde. T. \& Warden-Fernández, J. (2005). International and Comparative Mineral Law and Policy - Trends and Prospects. The Hague, Netherlands: Kluwer Law International.

Bindemann, K. (1999). Production-Sharing Agreements: An economic analysis. WPM 25, 0xford Institute for Energy Studies.

Bourguignon, F. \& Chakravarty, S.R. (2003). The measurement of multidimensional poverty. Journal of Economic Inequality, Apr 2003, pp. 25-49.

Brazil. (1997). The Regulation of the Petroleum Industry in Brazil (Law No. 9.478 of August 1997) (English translation). Brazil: Brasilia Energia Publishers, IBP - Instituto Brasileiro de Petróleo e Gás. [On-line] Available:

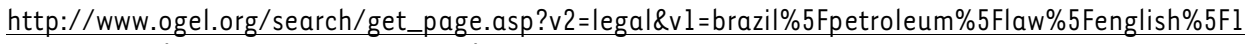
997\%2Epdf. (Accessed 28 August 2010)

CIA (Central Intelligence Agency). (2009). The World Factbook - Country comparison: Oil production. [On-line] Available: https://www.cia.gov/library/publications/the-world-

factbook/rankorder/2173rank.html. (Accessed 23 August 2010)

CIA (Central Intelligence Agency). (2010). The World Factbook - Country comparisons: Proven oil reserves. [On-line] Available: https://www.cia.gov/library/publications/the-world-

factbook/rankorder/2178rank.html. (Accessed 23 August 2010) 
CIA (Central Intelligence Agency). (2011). The World Factbook - Angola. [On-line] Available: https://www.cia.gov/library/publications/the-world-factbook/geos/ao.html. (Accessed 23 August 2011)

Davis, J., Ossowski, R., Daniel, J. \& Barnett, S. (2001). Oil Funds: Problems Posing as Solutions? Finance \& Development, 38(4). [Online] Available:

http://www.imf.org/external/pubs/ft/fandd/2001/12/davis.htm. (Accessed 20 August 2010).

Erikson, T. (2006). The Norwegian Petroleum Sector and the Government Pension Fund-Global. Unpublished document. [Online] Available:

http://www.regjerigen.no/upload/FIN/statens\%20pensjonsfonds/The_Norwegian_Petroleum_Sector te.pdf. (Accessed 20 August 2010).

Ernst, U.F.W. (2007). Stripped bare by the curse of plenty. From Curse to Cures: Practical Perspectives on Remedying the Resource Curse, 11 (1), pp. 1-6.

EIA (Energy Information Administration). (2010). Angola: Background. [0n-line] Available: http://www.eia.doe.gov/emeu/cabs/Angola/Background.html. (Accessed 20 August 2010)

EIA (Energy Information Administration). (2009a) Canada: Background. [On-line] Available: http://www.eia.doe.gov/emeu/cabs/Canada/Oil.html. (Accessed 25 August 2010)

દIA (Energy Information Administration). (2009b) United Arab Emirates: Oil. [0n-line] Available: http://www.eia.doe.gov/emeu/cabs/UAE/0il.html. (Accessed 30 0ctober 2010)

Farhan, M. (2008). Production Sharing Contract: A comparison with Concessionary System from the Political, Financial and Functional Point of View. Energy Law Journal, (18 December 2008)

Frynas, J.G. \& Paulo, M. (2006). A new scramble for African oil? Historical, political and business perspectives. African Affairs, 106/423, pp. 229-251.

Gallagher, M. \& Rozner, S. (2007). Tools for treating the resource curse. From Curse to Cures: Practical Perspectives on Remedying the Resource Curse, 11(1), pp. 28-34.

Garnaut, R. \& Clunnies-Ross, A. (1975). Uncertainty, risk aversion and taxing of natural resource projects. The Economic Journal, 85 (338), pp. 272-287.

Human Rights Watch. (2010). Transparency and Accountability in Angola - An Update. United States of America: Human Rights Watch.

IMF (International Monetary Fund). (2005). Angola: Selected issues and Statistical Appendix. IMF Country Report. 05/125.

Kolstad, I. \& Søreide, T. (2009). Corruption in natural resource management: Implication for policy makers. Resource Policy, (34), pp. 214-226.

Koptis, G. (2004). Rules-Based Fiscal Policy in Emerging Markets. Hampshire: Palgrave MacMillan.

Lambrechts, K., Darimani, A., Kabemba, C. \& Olaleye, C. (2009). Breaking the Curse: How Transparent Taxation and Fair Taxes can Turn Africa's Mineral Wealth into Development. Johannesburg: Open Society Institute of Southern Africa, Accra: Third World Network Africa, Nairobi: Tax Justice Network Africa, Johannesburg: Action Aid International, London: Christian Aid.

Larsen, E.R. (2003). Are Rich Countries Immune to the Resource Curse? Evidence from Norway's Management of Its Oil Riches. Discussion Paper No. 362. Statistics Norway, Norway.

Lund, D. (2009). Rent taxation for Non-renewable Resources. The Annual Review of Resource Economics, 2009(1), pp. 287-307. 
Lundberg, B., Karan, M. \& Ernst, U.F.W. (2007). Standing up to the resource curse: Three case studies. From curse to cures. Practical Perspectives on Remedying the Resource Curse, 11(1), pp. 22-27.

Mehlum, H., Moene, K. \& Torvik, R. (2006). Institutions and the resource curse. The Economic Journal, (116), pp. 1-20.

Mikesell, R.F. (1997). Explaining the resource curse, with special reference to mineral-exporting countries. Resources Policy, 23(4), pp. 191-199.

Muttitt, G. (2005). Production sharing agreements: Oil privatisation by another name? PLATFORM.

Norway. (1975). Act of 13 June 1975 No.35 relating to the Taxation of Subsea Petroleum Deposits, etc. (the Petroleum Taxation Act) (Translation). [On-line] Available:

http://www.regjeringen.no/en/dep/fin/Selected-topics/taxes-and-duties/Act-of-13-June-1975No-35-relating-to-th.html?id=497635. (Accessed 20 November 2010)

Ochieze, C. (2007). Fiscal Stability: To what extent can fiscal stability mitigate changing circumstances in a petroleum tax regime? OGEL. 5(2).

OPEC (Organization of the Petroleum Exporting Countries). (2010). Annual Statistics Bulletin 2009. Austria: Ueberreuter Print und Digimedia.

Otto, J.M., Andrews, C., Cawood, F., Doggett, M., Guj, P., Stermole, F., Stermole, J. \& Tilton J. (2006). Mining royalties: a global study of their impact on investors, government and civil society. Washington DC: The World Bank.

Otto, J.M. (2001). Fiscal Decentralization and Mining Taxation. The World Bank Group Mining Department.

Province of Alberta. (2009). Petroleum Royalty Regulation 2009 (Regulation 222/2008). Alberta Queen's Printer: Alberta.

Province of Alberta. (2000). Alberta Heritage Savings Trust Fund Act (Revised Statutes of Alberta 2000 Chapter A-23). Alberta Queen's Printer: Alberta.

Postali, F.A.S. (2009). Petroleum royalties and regional development in Brazil: The economic growth of recipient towns. Resources Policy, 34, pp. 205-213.

Rosenblum, D. (2011). Analyzing Angola's Economy: Recent past, present and future. [0n-line] Available:

http://www.consultancyafrica.com/index.php?option=com_content\&view=article\&id=692:analyzing -angolas-economy-recent-past-present-and-future- $\&$ catid $=87$ : african-finance- $a$ economy\&ltemid $=294$. (Accessed 23 August 2011)

Rutledge, I. (2004). The Sakhalin II PSA - a Production 'Non-Sharing'Agreement. PLATFORM.

Sachs, J.D. \& Warner, A.M. (2001). The curse of natural resources. European Economic Review, 45, pp. 827-838.

Sarraf, M. \& Jiwanji, M. (2001). Beating the resource curse: The case of Botswana. The World Bank. (Working paper 24753).

Sala-i-Martin, X. \& Subramanian, A. (2003). Addressing the natural resource curse: An illustration from Nigeria. International Monetary Fund, Washington DC. ( IMF Working Paper WP/03/139).

Suleiman, A. (s.a.). The United Arab Emirates. (In Encyclopaedia of Hydrocarbons - Volume IV / Hydrocarbons: Economics, Policies and Legislation, pp. 773-784). 
SWFI (Sovereign Wealth Fund Institute). (2009). Angola: Fundo Soberano Angolano. [0n-line] Available: http://www.swfinstitute.org/fund/angola.php. (Accessed 10 November 2010)

Tsalik, S. (2004). Caspian Oil Windfalls: Who will benefit? New York: Open Society Institute.

Van den Bergh, J.C.J.M. (2009). The GDP Paradox. Journal of Economic Psychology, 30, pp. 17-135.

UNCTAD (United Nations Conference on Trade and Development). (2007). World Investment Report 2007: Transnationa/ Corporations: Extractive Industries and Development. New York/Geneva: United Nations Publications.

UNCTAD (United Nations Conference on Trade and Development). (2005). Economic Development in Africa: Rethinking the Role of Foreign Direct Investment. New York/Geneva: United Nations Publications.

UNDP (United Nations Development Programme). (2009). Human Development Report 2009Overcoming barriers: Human mobility and development. Hampshire: Palgrave MacMillan.

Wälde, T.W. (1995). The current status of international Petroleum Investment: Regulating, Licensing, Taxing and Contracting. CEPMLP Journal, 1(5). [Online] Available:

http://www.dundee.ac.uk/cepmlp/journal/html/Voll/articlel-5.html. (Accessed 28 August 2010).

World Bank. (2006). Angola, Country Economic Memorandum: Oil, Broad-Based Growth and Equity. Report No 35262-A0: The World Bank. 